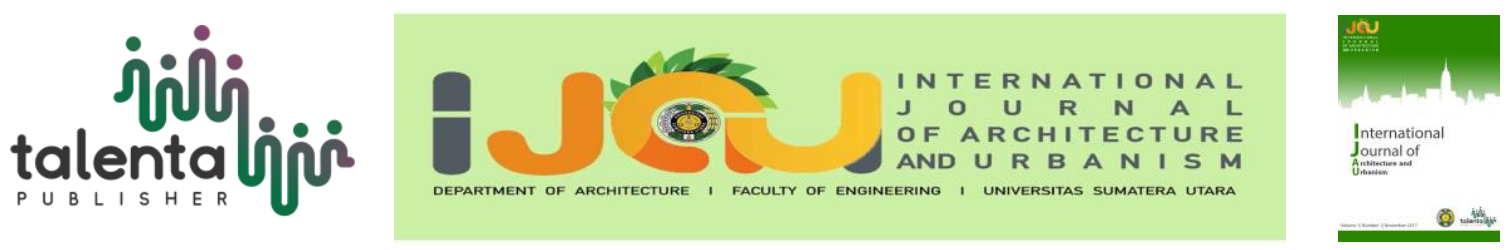

\title{
Design of Medan Fine Art Museum with the Application of Futuristic Architecture
}

\author{
Rahman, V. N. ${ }^{1^{*}}$, Rahmah Y.A. ${ }^{I}$ \\ ${ }^{1}$ Architecture Departement, Faculty of Engineering, Universitas Sumatera Utara, Medan, Indonesia
}

\begin{abstract}
The Futuristic architecture is a concept that illustrates the planning and development is not based on something related to the past, but try to describe the future. The futuristic architecture concept is applied to bring a new style to the building. The purpose is to eliminate the ancient impression on the building of the Fine Art Museum in Medan. The Medan Fine Arts Museum was designed as a recreation and education place to learn about fine art. Other than a place to store and preserve works of art, The Museum also provides a variety of facilities. The methodology of these projects starts with literature studies, site selection, site observation, and concept design. After carrying out these steps, the concept of space and the shape of the Museum building can be determined. Therefore, by designing this Medan Fine Art Museum with the application of Futuristic Architecture, it is hoped can increase the attractiveness of visitors and make an educative recreational place in Medan.
\end{abstract}

Keyword: fine arts, futuristic, museum

\section{Introduction}

The Development of art in Indonesia has reached the stage of modern art. Art painting and sculpture are part of the most dominant fine art among other branches of art. All fine arts are works of art that are tried to be visualized, expressed through communication media.

Furthermore, art is enjoyed, understood, and practiced. Medan is the third-largest city in Indonesia. There are so many fine art galleries in Medan. However, the gallery in Medan still cannot be stated as a place to preserve Fine Arts. A less attractive place makes a fine art gallery in Medan reluctantly to be visited.

Based on the problems above, it is needed a container in the form of Fine Arts Museum in Medan, so the artist in Medan can display their works to be known by the society, whether it is local or outside the region. By applying the concept of futuristic architecture, it will give a unique impression of a Museum, so the tourist will be more interested in visiting it.

*Corresponding author at: Architecture Department, Faculty of Engineering, Universitas Sumatera Utara, Jalan Perpustakaan Gedung J07, Medan 20155, Indonesia

E-mail address: vinkyrahman@gmail.com 


\section{Literature Review}

\section{Museum of Art}

A museum is a foundation, storage, maintenance, security, and the use of material from human culture, nature, and environment to support the efforts to protect and preserve national cultural wealth (Republic of Indonesia government regulation No.19 of 1995).

Fine art is one of the branches of art; art is an expression of human ideas and feelings through median processing, element structuring, and principles designing. Fine art is the realization of unlimited imagination, and there is not any limit in the work of art. Soin, the work of art, will not run out of ideas. In pure art, the work created is a two-dimensional and three-dimensional form. So that the object created is the result of one or more of the existing media (to be noted that the media or art material in the world is also unlimited) [1].

The function of the Fine Arts Museum building is as a place to store and preserve all works of art in Medan city, as well as an educational recreation place where education is provided on fine arts and how to create a work.

\section{Theme}

Futuristic is an understanding of freedom in expressing ideas into a form of unusual, creative, and innovative appearance. The outcome of this futuristic is something dynamic, always changing according to the desires and times. This futuristic application can only be seen in appearance or, it seems to keep paying attention and taking into account the function of the object [2].

There are two important things that become the principle of futuristic architecture; (a) Capability and flexibility are the ability of the building to adjust and follow the demands and requirements of the building. Futuristic buildings can follow and accommodate the demands of activities that are constantly evolving and can serve changes in the activity of the event. (b) The futuristic architecture contains dynamic, aesthetic, and innovative values, especially in terms of the technology used to adopt free forms that are not bound by certain forms [3].

\section{Methodology}

Site selection criteria are based on the Medan City General Spatial Plan. Based on the Medan General Spatial Plan, the chosen location is the area designated for residential areas, offices, recreation, and golf courses. This location is suitable to be used as a design site for the Medan Fine Arts Museum because the site is far from the crowds, making it suitable as an indoor recreation area, and there is a security institution near the Museum. 
The architectural and non-architectural design stages are carried out in stages starting with the collection of primary and secondary data into consideration in the design, which will then produce basic concepts, site concepts, circulation concepts, concepts of mass composition, concepts of plans, structures and the utilities. The final stage of the design is a working image that contains plans, looks, pieces, details to the perspective of the exterior and interior.

\section{Result and Discussion}

The design of the Medan Fine Arts Museum is located on St. TB Simatupang Pinang Baris, Medan Sunggal, Medan City, North Sumatra. Medan Sunggal area is intended as an outdoor tourist and educational place. Consideration of choosing the site location is based on criteria in building a museum. With the existing site conditions like (Figure 1).

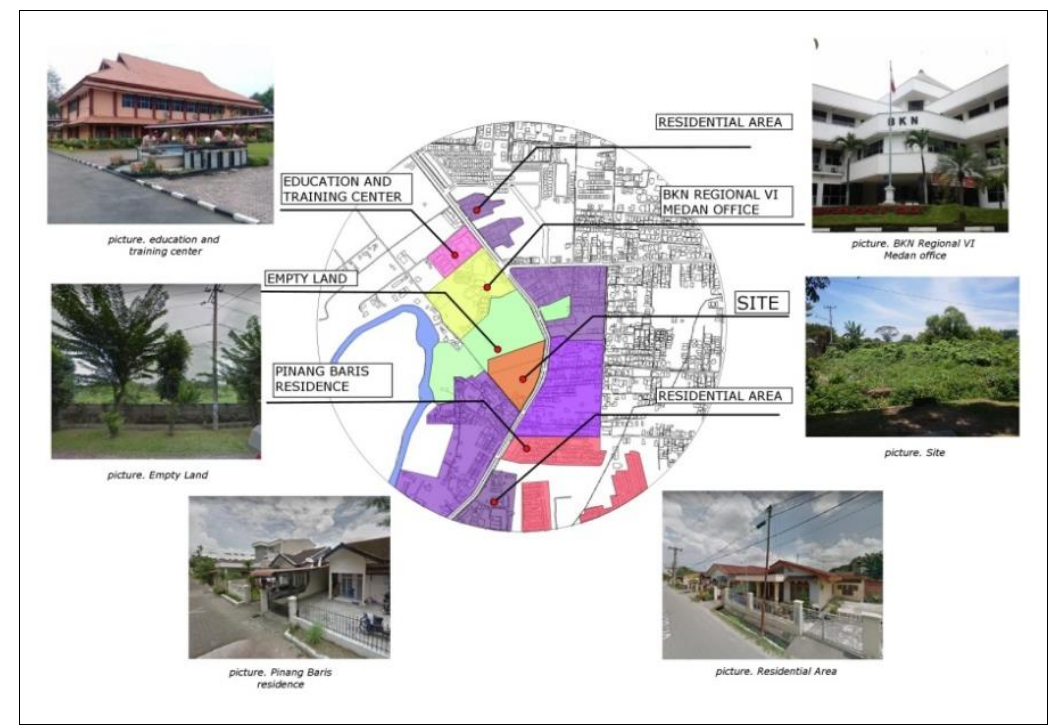

Figure 1. The existing condition of the site

The application of futuristic design is carried out by considering two criteria, namely capability and flexibility. The application of futuristic designs is then described in 3 design points ; (a) Space processing, (b) Material processing, (c) View processing [4].

\section{Space Processing}

Zones distributions in the building of the Medan Fine Arts Museum are based on the analysis and results of field surveys to get the results of zoning (Figure 2). 


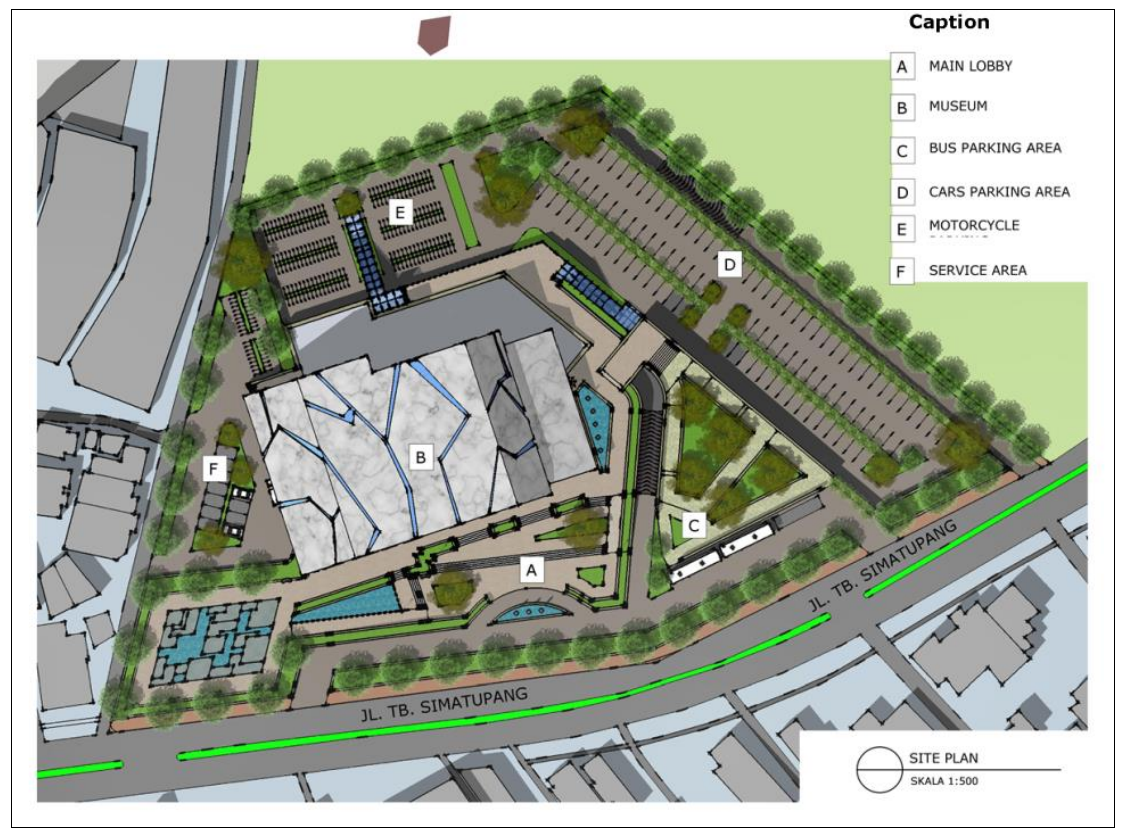

Figure 2. Siteplan Design

Spacing is based on the needs and character of the user, and the activities carried out to serve and follow the times, dynamic, time simplicity, and place or space in all aspects of it. A multifunctional space system, such as the 1st-floor hall room in the Museum building (Figure $3)$.

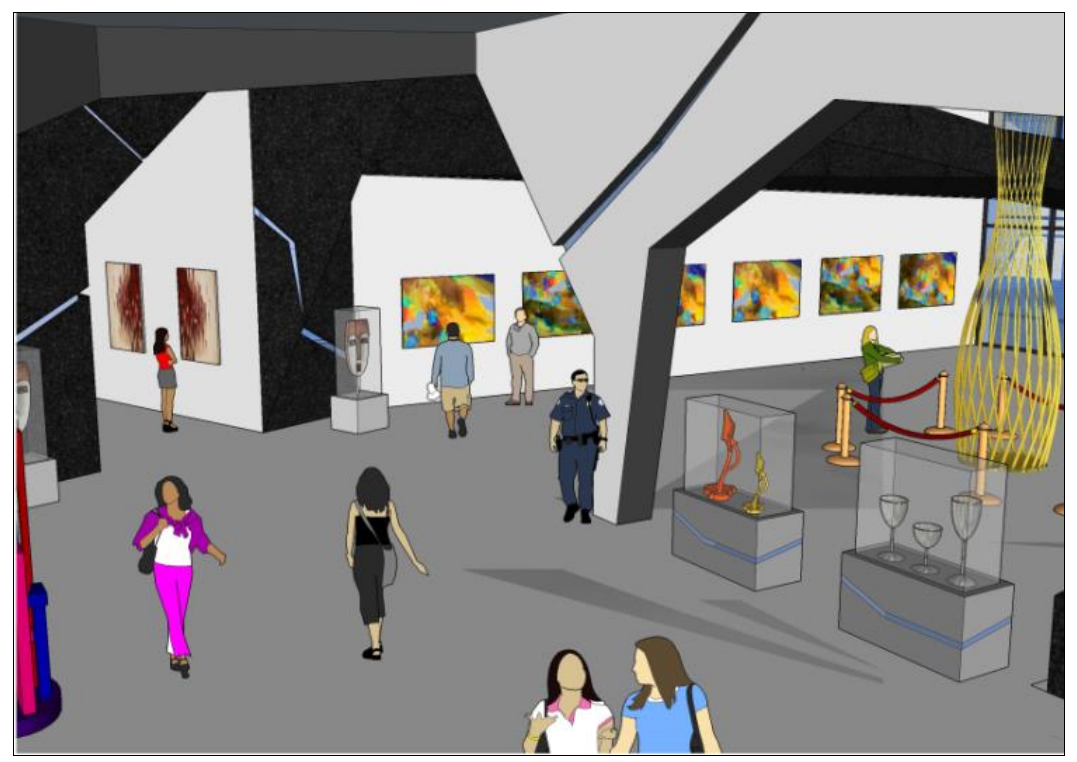

Figure 3. Hall museum

\section{Material Processing}

Using wall-based materials and metal-based structures such as the Aluminum Composite Panel (ACP), which has a pattern (Figure 4). 


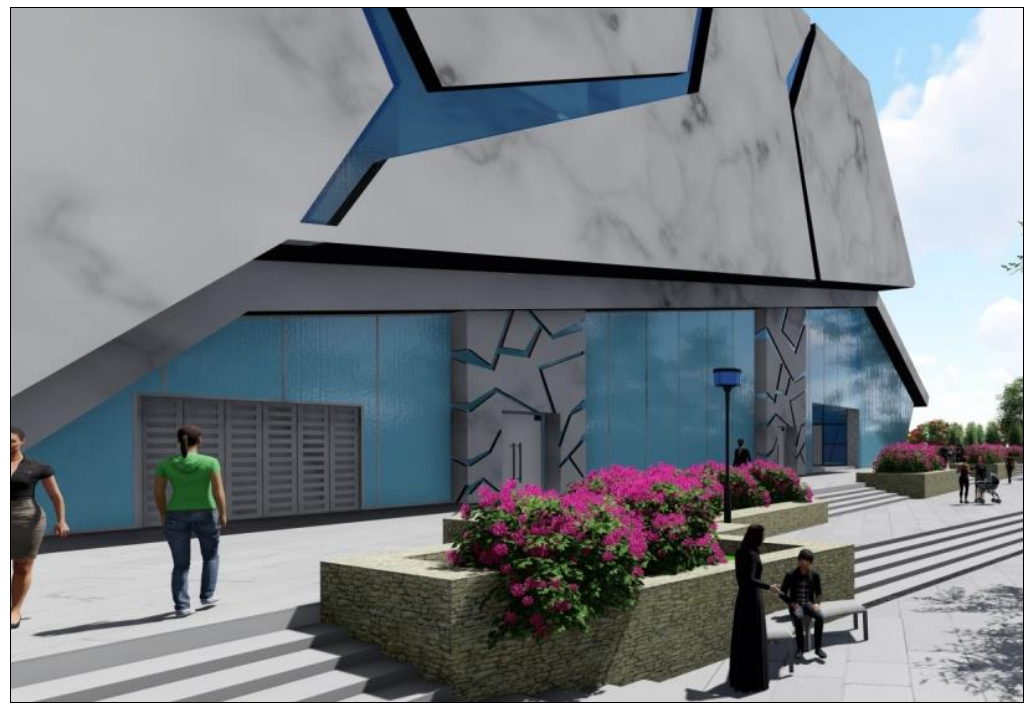

Figure 4. ACP material on the wall layer

Smart Glass Facades indicate an ability to respond to the changes in natural environmental conditions according to the time of day or throughout the year in such a way as to reduce primary energy requirements for natural heating, cooling, and lighting, which will ultimately contribute to environmental conservation [5]. Smart glass facades are applied to the buildings (Figure 5).

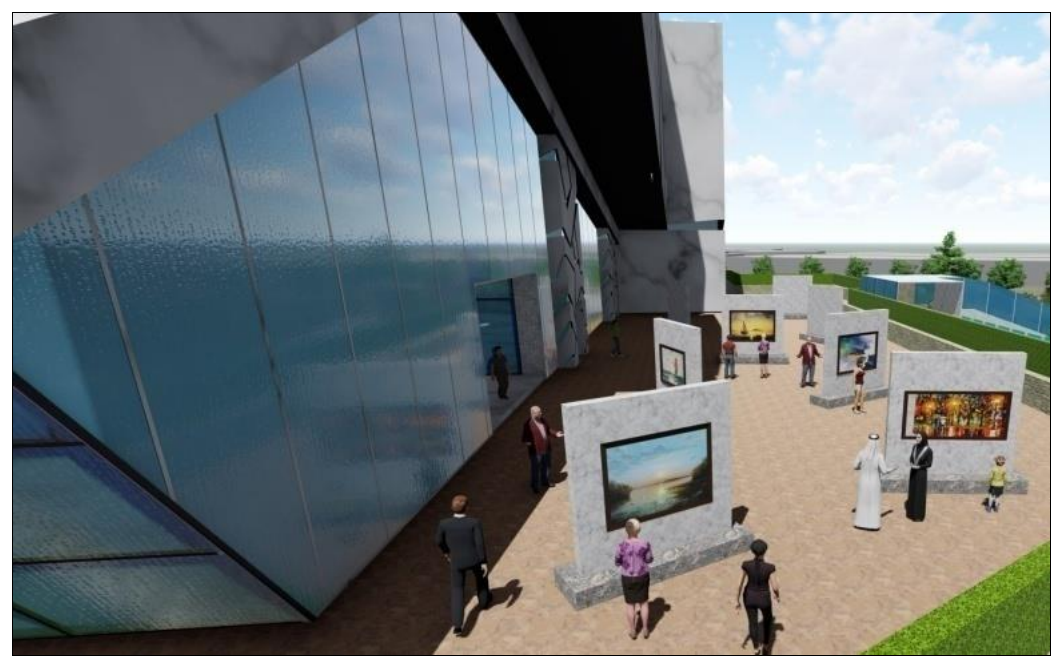

Figure 5. Glass facade

I am using Solar Cells on the roof to get the alternative sources of electrical energy obtained from the heat of the sun to fulfill the needs of every activity in the Museum (Figure 6). 


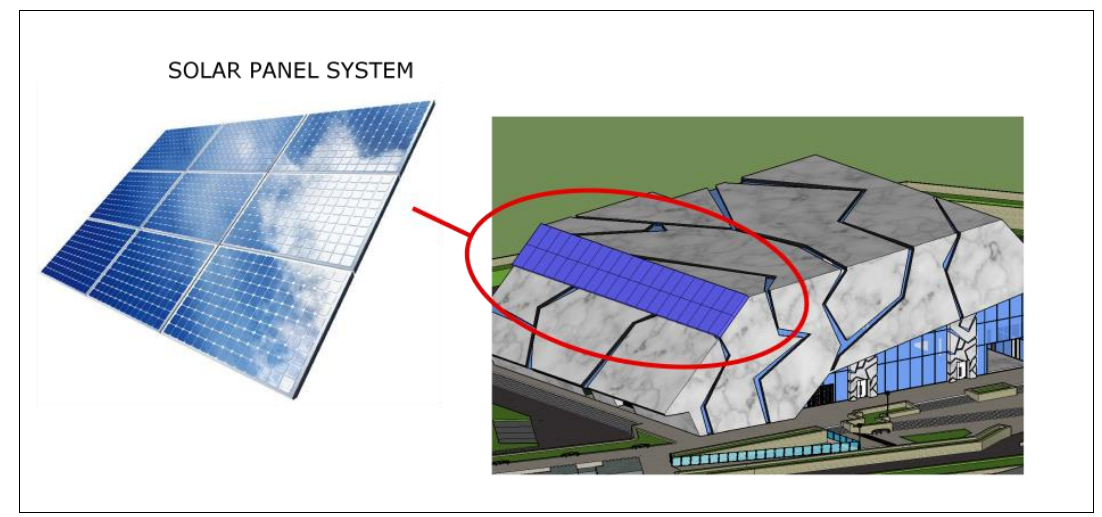

Figure 6. The using of Solar Cell

\section{View Processing}

According to the principle of futuristic architecture, It can be concluded that the character of Futuristic Architecture are: (a) take patterns from geometric or abstract forms (free forms) that are deconstructed so that the shapes are monotonous and simple (b) less is more, the simpler is an additional value the design emphasis on space then the design becomes plain. So that, basic forms concept for the building of the Medan Fine Arts Museum (Figure 7).

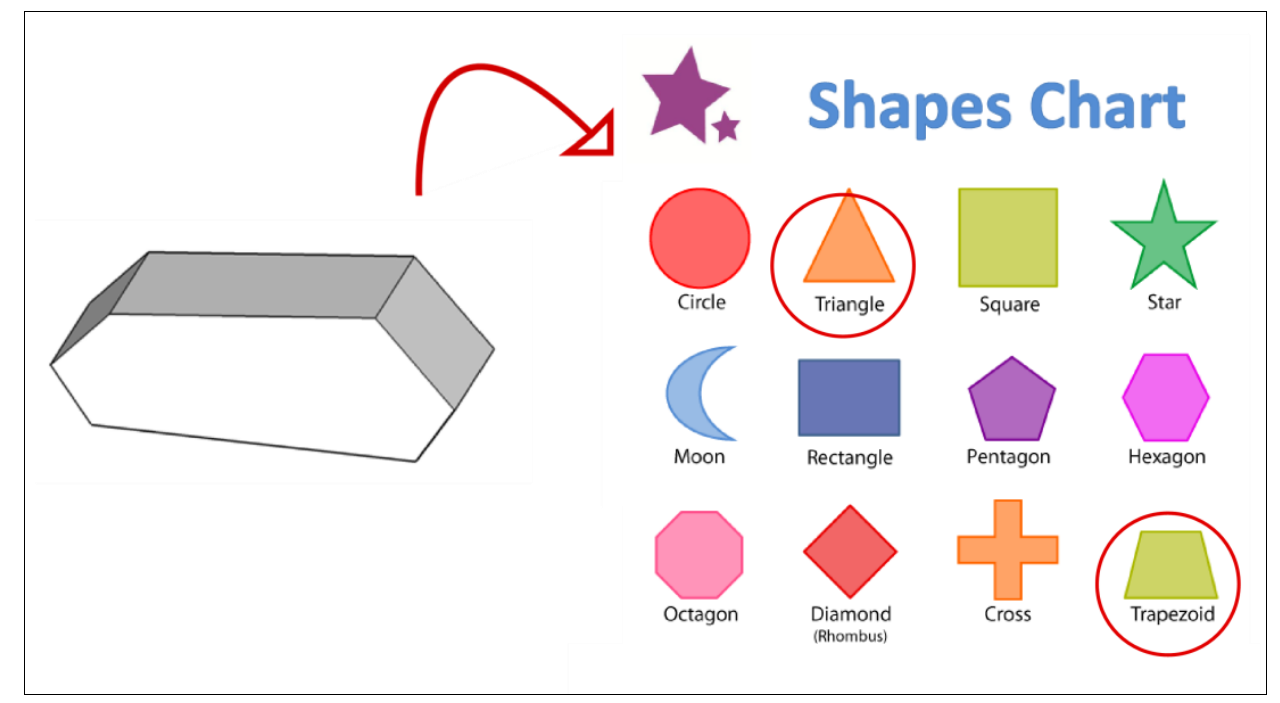

Figure 7. Basic Shape

Take geometric collisions from the combined of trapezoidal and triangle shape. Both shapes are carefully arranged to get a unique view.

After being combined, the form is divided into two and add a level difference to make it not too monotonous and add space to the building (Figure 8). 


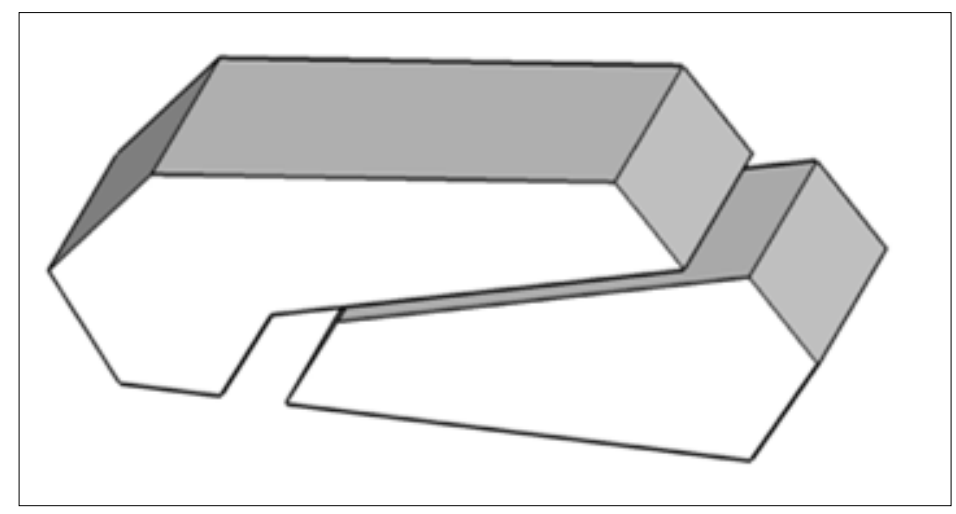

Figure 8. Mass composition

Adding patterns of abstract lines as the additional value for visuals as well as functioning as a place of lighting. From the basic form concept, so the Art Museum buildings are designed like (Figure 9).

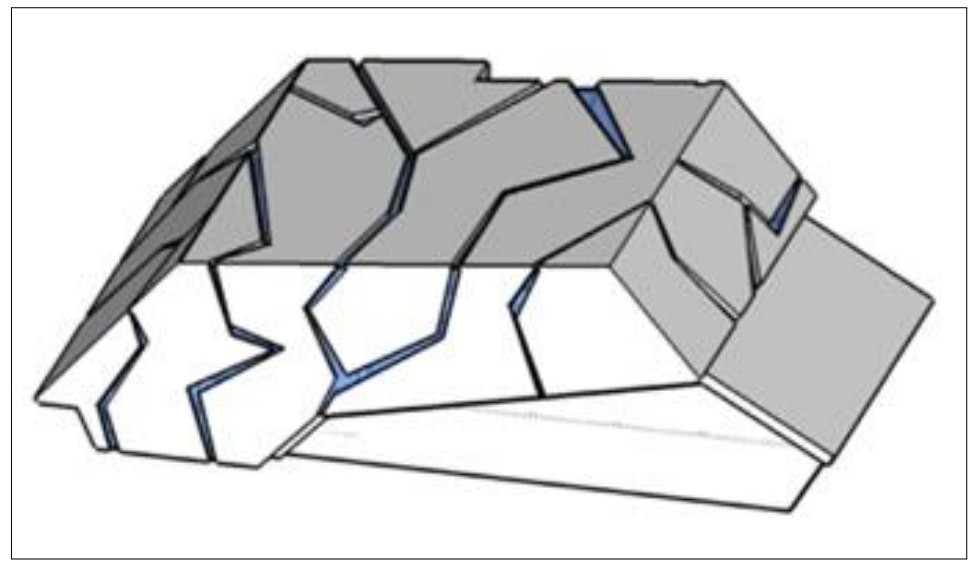

Figure 9. Adding the abstract line

\section{Structure Processing}

The museum building uses a rigid structure using a rigid frame system. The rigid frame system consists of a lattice, a vertical column, and a horizontal beam that is transferred to a field using a rigid connection. The principle of a rigid frame will be economical up to 30 floors for steel frames, and 20 floors for concrete frames. Some typical building frames are shown in (figure 10), using the Truss structure on the roof due to a more flexible structure for wide span buildings like the (figure 11). 


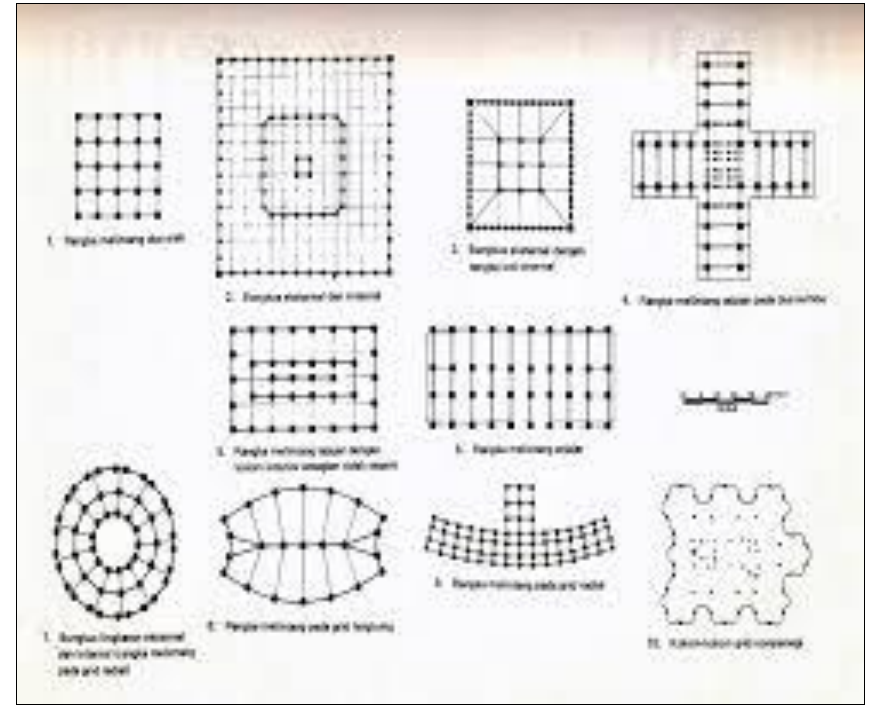

Figure 10. Rigid Frame Structure System

(Source: doc.site, high building structure system, accessed in September 2018)

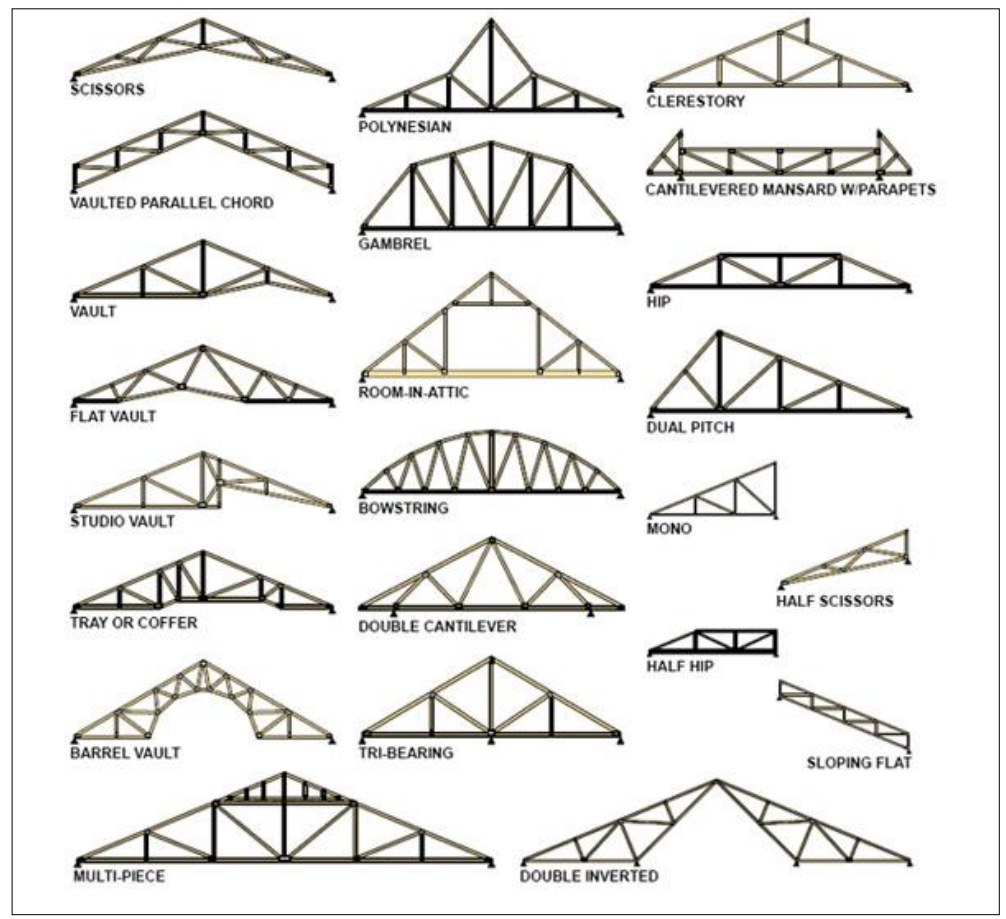

Figure 11. Truss Structure System

(Source: bajaringankania.com, accessed in September 2018)

By considering the basic concepts and the use of materials and structures, then The following is the atmosphere of the Medan Fine Arts Museum building designed with a futuristic concept. Putting some trees is useful to make the building not look too dry. The color used on the outside is gray and white, where the color is produced from the material (Figure 12). 


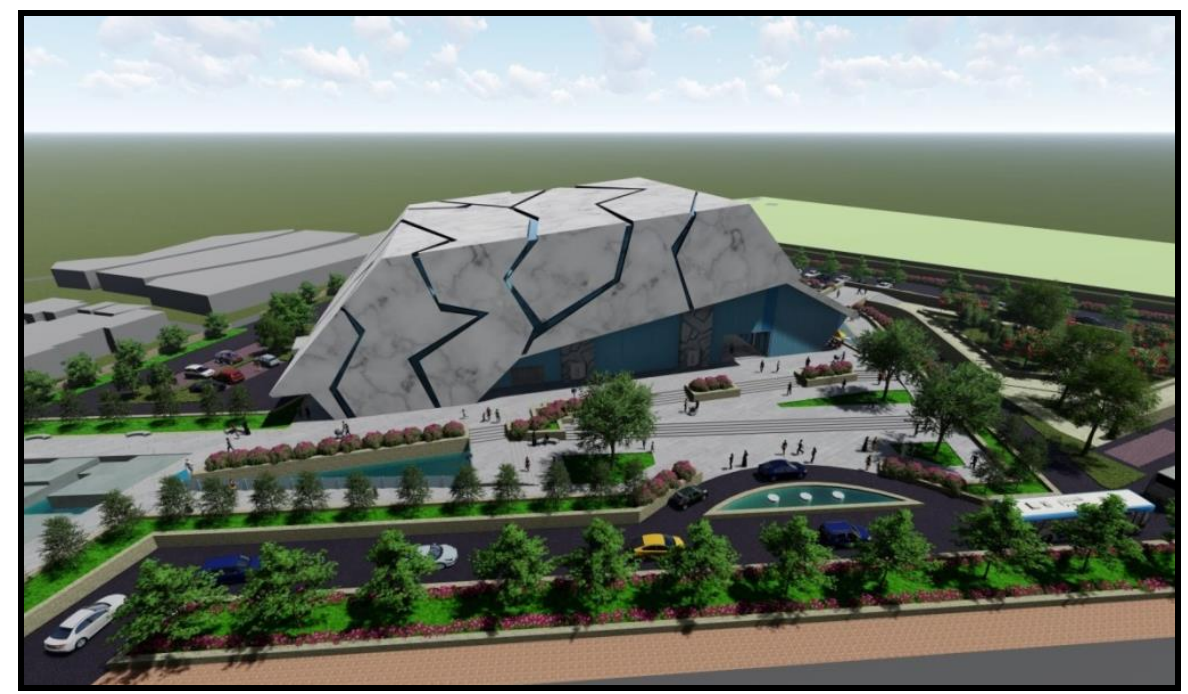

Figure 12. Siteplan Design

\section{Conclusion}

The location of the Medan Fine Arts Museum is on Jl. TB Simatupang Pinang Baris, Sunggal, Medan City, North Sumatra. Medan Sunggal area is intended as an outdoor tourist and educational place. Selection of site locations based on criteria in building a museum. The chosen site is far from the crowd, and there is a security institution near the site.

The concept of futuristic architecture is applied in the form of a building that takes the form of a trapezoid and a triangle that is combined in such a way. Buildings are given irregular abstract lines as if giving effect to cracks in buildings. At the crack line, the glass layer useful to facilitate incoming light to the building. The museum building has few open parts to keep the temperature in the room, so it will not affect the sensitive display objects. The material used is also adjusted to the criteria of the Futuristic Architecture that uses materials such as glass, aluminum, plates, acrylic, and others.

\section{Acknowledgment}

This researchers have prepared this article and was partly funded by the Department of Architecture Universitas Sumatera Utara as a contribution to the city government in planning and design to maintain existing local wisdom.

\section{REFERENCES}

[1] Budi. C, Konsep Dasar Seni Rupa Sd, Pendidikan Seni Rupa PGSD, FKIP, UMS, 2010, p.2.

[2] Tiffany, "Medan Science and Tecnology Center," Skripsi Sarjana, 2012.

[3] Chotijah Kusumawati, "Arsitektur Modern Pertengahan Konsep Aliran," 2008. 
[4] M.Musyawaroh, \& A.Sumadyo T.Adhiyatama, "Pusat Pameran dan Konvensi di Surakarta; dengan Pendekatan Arsitektur Futuristik," Senthong, p. 1, 2018.

[5] R. Amanati, P. Aldy S. Haryadi, "Pekanbaru Concention Center; dengan Penekanan Banguna Futuristik," Jurnal Online Mahasiswa Fakultas Teknik Universitas Riau, pp. 114, 2015. 